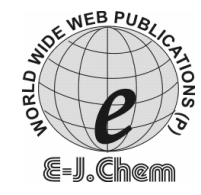

http://www.e-journals.net
ISSN: 0973-4945; CODEN ECJHAO

E-Journal of Chemistry

Vol. 5, No.3, pp. 515-520, July 2008

\title{
Spectrophotometric Determination of Gemifloxacin Mesylate in Pharmaceutical Formulations Through Ion-Pair Complex Formation
}

\author{
MAROTHU VAMSI KRISHNA* and DANNANA GOWRI SANKAR \\ Pharmaceutical Analysis and Quality Assurance Division, \\ College of Pharmaceutical Sciences, \\ Andhra University, Visakhapatnam, India. \\ marothu_vamsi@rediffmail.com
}

Received 20 April 2007; Accepted 10 June 2007

\begin{abstract}
Four simple and sensitive ion-pairing spectrophotometric methods have been described for the assay of gemifloxacin mesylate (GFX) either in pure form or in pharmaceutical formulations. The developed methods involve formation of colored chloroform extractable ion-pair complexes of the drug with safranin O (SFN O) and methylene blue (MB) in basic medium; Napthol blue 12BR (NB 12BR) and azocaramine $\mathrm{G}(\mathrm{AG})$ in acidic medium. The extracted complexes showed absorbance maxima at 525, 650, 620 and $540 \mathrm{~nm}$ for SFN O, MB, NB 12BR and AG, respectively.Beer's law is obeyed in the concentration ranges $3-15,4-20,2-10$ and $2-10 \mu \mathrm{g} / \mathrm{mL}$ with molar absorptivity of $2.81 \times 10^{4}, 2.20 \times 10^{4}, 4.02 \times 10^{4}$ and $4.15 \times 10^{4} \mathrm{~L} \mathrm{~mole}^{-1} \mathrm{~cm}^{-1}$ and relative standard deviation of $0.077,0.104,0.080$ and $0.103 \%$ for SFN O, MB, NB 12BR and AG, respectively. These methods have been successfully applied for the assay of drug in pharmaceutical formulations. No interference was observed from common pharmaceutical adjuvants. Results of analysis were validated statistically and through recovery studies.
\end{abstract}

Keywords: Gemifloxacin Mesylate, Ion-pair complex formation, Spectrophotometry.

\section{Introduction}

Gemifloxacin, (R,S)-7-(3-aminomethyl-4-syn-methoxyimino-1-pyrrolidinyl)-1-cyclopropyl6-fluoro-1,4-dihydro-4-oxo-1,8-naphthyridine-3-carboxylicid methanesulfonate, is a new fluoroquinolone antibacterial compound with enhanced affinity for bacterial topoisomerase IV and is being developed for the treatment of respiratory and urinary tract infections. The compound has a broad spectrum of activity against Gram-positive and Gram-negative bacteria $^{1-3}$. Literature survey revealed that few analytical methods have been reported for the estimation of GFX; they include high-performance liquid chromatography-tandem mass 
spectrometry (LC-MS-MS) ${ }^{4-5}$, microchip electrophoresis ${ }^{6}$, chiral high-performance liquid chromatography ${ }^{7}$ and chiral counter-current chromatography ${ }^{8}$. To the best of our knowledge, there is no work in the literature reported about the spectrophotometric method for the analysis of GFX in either biological fluids or pharmaceutical formulations. Hence the author has made an attempt to develop four simple and rapid spectrophotometric methods for the estimation of GFX in bulk drugs and in pharmaceutical formulations. The developed methods involve formation of colored chloroform extractable ion-pair complexes of the drug with safranin $\mathrm{O}$ and methylene blue in basic medium; napthol blue $12 \mathrm{BR}$ and azocaramine $\mathrm{G}$ in acidic medium. The extracted complexes showed absorbance maxima at 525, 650, 620 and $540 \mathrm{~nm}$ for SFN O, MB, NB 12BR and AG, respectively.

\section{Experimental}

\section{Apparatus}

All spectral and absorbance measurements were made on a Systronic Model 117 digital spectrophotometer with $10 \mathrm{~mm}$ matched quartz cells.

\section{Materials and reagents}

All chemicals used were of analytical reagent grade and double distilled water was used for preparing the reagent solutions. SFN O $(0.2 \%)$ solution was prepared by dissolving $200 \mathrm{mg}$ of safranin $\mathrm{O}$ in $100 \mathrm{~mL}$ of distilled water. MB $(0.2 \%)$ solution was prepared by dissolving $200 \mathrm{mg}$ of methylene blue in $100 \mathrm{~mL}$ of distilled water. Ammoniaammonium chloride buffer solution ( $\mathrm{pH} 9.8$ ) was prepared by mixing $7 \mathrm{~g}$ of ammonium chloride with $56.8 \mathrm{~mL}$ of liquor ammonia solution and diluted to $100 \mathrm{~mL}$ with distilled water and $\mathrm{pH}$ was adjusted to 9.8 . NB $12 \mathrm{BR}(0.2 \%)$ solution was prepared by dissolving $200 \mathrm{mg}$ of napthol blue 12BR in $100 \mathrm{~mL}$ of distilled water. AG $(0.05 \%)$ solution was prepared by dissolving $50 \mathrm{mg}$ of azocaramine $\mathrm{G}$ in $100 \mathrm{~mL}$ of distilled water containing traces of sodium hydroxide. $0.1 \mathrm{M} \mathrm{HCl}$ was prepared by diluting $8.6 \mathrm{~mL}$ of concentrated hydrochloric acid to $1000 \mathrm{~mL}$ with distilled water and standardized. $\mathrm{pH}$ 1.5 buffer solution was prepared by mixing $289 \mathrm{~mL}$ of glycine solution $(37.52 \mathrm{~g}$ of glycine and $29.24 \mathrm{~g}$ of NaCl were dissolved in $500 \mathrm{~mL}$ distilled water) with $711 \mathrm{~mL}$ of $0.1 \mathrm{M} \mathrm{HCl}$ and the $\mathrm{pH}$ of the solution was adjusted to 1.5 .

\section{Preparation of standard stock solutions}

Stock solution of GFX was freshly prepared by dissolving 100mg of GFX in $100 \mathrm{~mL}$ of distilled water and then this was further diluted with distilled water so as to obtain working standard solution of $60 \mu \mathrm{g} / \mathrm{mL}$ for SFN O, $80 \mu \mathrm{g} / \mathrm{mL}$ for MB, $40 \mu \mathrm{g} / \mathrm{mL}$ for NB 12BR and AG.

\section{General procedures}

\section{For $S F N O$ and $M B$}

Different aliquots of standard solution $(60 \mu \mathrm{g} / \mathrm{mL}$ for SFN O and $80 \mu \mathrm{g} / \mathrm{mL}$ for MB) from $0.5-2.5 \mathrm{~mL}$ and $1.0 \mathrm{~mL}$ of $\mathrm{pH} 9.8$ buffer solution were placed separately in a series of $125 \mathrm{~mL}$ separating funnels. A volume of $1.5 \mathrm{~mL}$ of $\mathrm{SFN} \mathrm{O}$ or $0.5 \mathrm{~mL}$ of $\mathrm{MB}$ was added respectively. The total volume in each funnel was adjusted to $10 \mathrm{~mL}$ with distilled water. Then $10 \mathrm{~mL}$ of chloroform was added to each separating funnel and the contents were shaken for 5 minutes and allowed to separate. The organic layer was collected through cotton plug and the absorbance was immediately measured at $525 \mathrm{~nm}$ for SFN $\mathrm{O}$ and at $650 \mathrm{~nm}$ for MB against the reagent blank. Both the colored species were stable for 1 hour. The calibration curves were constructed by plotting the absorbance versus final concentration of 
GFX. The amount of the drug was computed either from calibration curve or from regression equation.

\section{For $N B 12 B R$ and $A G$}

In to a series of $125 \mathrm{~mL}$ separating funnels containg aliquots of standard GFX solution (0.5$2.5 \mathrm{~mL}, 40 \mu \mathrm{g} / \mathrm{mL}$ ), $6.0 \mathrm{~mL}$ of $0.1 \mathrm{M} \mathrm{HCl}$ (for NB 12BR), or buffer solution $\mathrm{pH} 1.5$ (AG) and $2.0 \mathrm{~mL}$ of dye solution were added. The total volume of aqueous phase in each separating funnel was adjusted to $15 \mathrm{~mL}$ with distilled water and $10 \mathrm{~mL}$ of chloroform was added. The contents were shaken for 2 minutes and allowed to separate. The organic layer was collected through cotton plug and the absorbance was immediately measured at $620 \mathrm{~nm}$ for NB 12BR and at $540 \mathrm{~nm}$ for AG against the reagent blank. Both the colored species were stable for 1 hour. The calibration curves were constructed by plotting the absorbance versus final concentration of the GFX. The amount of the drug was computed either from calibration curve or from regression equation.

\section{Procedure for the assay of the tablets}

Twenty tablets were weighed accurately and ground in to a fine powder. An amount of powder equivalent to $50 \mathrm{mg}$ of GFX was weighed into a $100 \mathrm{~mL}$ volumetric flask, about $20 \mathrm{~mL}$ of water containing $10 \mathrm{~mL}$ of the methanol were added and shaken thoroughly for about $20 \mathrm{~min}$, then the volume was made up to the mark with the water, mixed well and filtered using a whatman filter paper \#42 and the first few milliliters of the filtrate were discarded. The procedure was continued as mentioned under general procedures

\section{Results and Discussion}

GFX forms ion-pair complexes in basic buffer with dyestuffs such as SFN O and MB and these complexes are quantitatively extracted into chloroform. The ion-pair complexes with SFN O and MB absorbed maximally at 525 and $650 \mathrm{~nm}$ respectively. GFX also forms ionpair complexes in acidic medium with dyestuffs such as NB 12BR and AG and these complexes are quantitatively extracted into chloroform. The ion-pair complexes with NB 12BR and AG absorbed maximally at 620 and $540 \mathrm{~nm}$ respectively. Optimum conditions established for these methods were presented in Table 1 and 2.

The optical characteristics such as Beer's law limits, Sandell's sensitivity, molar absorptivity, percent relative standard deviation (calculated from eight replicate samples containing $3 / 4^{\text {th }}$ of the amount of the upper beer's law limits) were calculated for all the methods and the results are summarized in Table 3. Regression characteristics like standard deviation of slope $\left(\mathrm{S}_{\mathrm{b}}\right)$, standard deviation of intercept $\left(\mathrm{S}_{\mathrm{a}}\right)$, standard error of estimation $\left(\mathrm{S}_{\mathrm{e}}\right)$, \% range of error (0.05 and 0.01 confidence limits) and detection limit were calculated for all the methods and are shown in Table 3.

Commercial formulation of GFX was successfully analyzed by the proposed methods. The values obtained by the proposed methods are presented in Table 4 . The reliability of the proposed method was checked by standard addition method. The results (Table 5) show that the mean recoveries were found in the range 100.0-100.05 with RSD $\leq 0.55 \%$ for SFN O, 100.01-100.08 with RSD $\leq 0.54$ for MB, 100.05-100.12 with RSD $\leq 0.61$ for NB $12 B R$ and 100.01-100.16 with RSD $\leq 0.57$ for AG. Interference studies revealed that the common excipients and other additives usually present in dosage form did not interfere in the proposed methods. The performance order of the proposed methods is AG $>$ NB $12 B R>$ SFN O $>$ MB. 
Table 1. Optimum conditions established for SFN O and MB

\begin{tabular}{|c|c|c|c|}
\hline Parameter & $\begin{array}{l}\text { Optimum } \\
\text { range }\end{array}$ & $\begin{array}{l}\text { Conditions } \\
\text { in } \\
\text { procedure }\end{array}$ & Remarks \\
\hline $\begin{array}{l}\text { Effect of buffer } \mathrm{pH} \text { on } \\
\text { color development }\end{array}$ & $9.0-10.0$ & pH-9.8 & $\begin{array}{l}\text { Variations of the } \mathrm{pH}<6 \text { and }>11 \\
\text { resulted in low absorbance values }\end{array}$ \\
\hline $\begin{array}{l}\text { Volume of buffer } \\
\text { required for maximum } \\
\text { intensity of color }\end{array}$ & $0.5-1.5 \mathrm{~mL}$ & $1.0 \mathrm{~mL}$ & $\begin{array}{l}1 \mathrm{~mL} \text { of buffer is preferable for } \\
\text { maintenance of } \mathrm{pH} 9.8\end{array}$ \\
\hline $\begin{array}{l}\text { Effect of volume of } \\
\text { dye }\end{array}$ & $\begin{array}{l}1.0-2.0 \mathrm{~mL} \\
\text { for SFN O } \\
0.3-0.8 \mathrm{~mL} \\
\text { for } \mathrm{MB}\end{array}$ & $\begin{array}{l}1.5 \mathrm{~mL} \text { of } \\
\text { SFN O } \\
0.5 \mathrm{~mL} \text { of } \\
\mathrm{MB}\end{array}$ & $\begin{array}{l}1.5 \mathrm{~mL} \text { of SFN O and } 0.5 \mathrm{~mL} \text { of } \mathrm{MB} \\
\text { was necessary for covering the broad } \\
\text { range of Beer's law. }\end{array}$ \\
\hline $\begin{array}{l}\text { Choice of the organic } \\
\text { solvent for the } \\
\text { extraction of the colored } \\
\text { species }\end{array}$ & Chloroform & Chloroform & $\begin{array}{l}\text { The other water immiscible solvents } \\
\text { tested for the extraction of the colored } \\
\text { complex into organic phase include } \\
\text { chlorobenzene, dichloromethane, } \\
\text { carbon tetrachloride, } n \text {-butanol and } \\
\text { benzene. Chloroform was preferred } \\
\text { for its selectivity extraction of the } \\
\text { complex from the aqueous phase. }\end{array}$ \\
\hline $\begin{array}{l}\text { Effect of the ratio of } \\
\text { aqueous to organic } \\
\text { phase on extraction }\end{array}$ & $1: 1$ & $1: 1$ & $\begin{array}{l}\text { The extraction of the colored species } \\
\text { into chloroform layer was incomplete, } \\
\text { where the ratio of aqueous to } \\
\text { chloroform phase was more than the } \\
\text { specified ratio in each case. }\end{array}$ \\
\hline Effect of shaking time & $3-8 \min$ & $5 \mathrm{~min}$ & $\begin{array}{l}\text { Constant absorbance values were } \\
\text { obtained for the shaking period 3-8 min. }\end{array}$ \\
\hline $\begin{array}{l}\text { Effect of temperature } \\
\text { on the colored species }\end{array}$ & $\begin{array}{l}\text { Laboratory } \\
\text { temperature } \\
\left(28 \pm 2^{0} \mathrm{C}\right)\end{array}$ & $\begin{array}{l}\text { Laboratory } \\
\text { temperature }\end{array}$ & $\begin{array}{l}\text { At low temperature }\left(<20^{0} \mathrm{C}\right) \text { the } \\
\text { extraction of the colored species was } \\
\text { found to be improper. At high } \\
\text { temperature }\left(>35^{0} \mathrm{C}\right) \text { the stability of the } \\
\text { colored species was found to be less. }\end{array}$ \\
\hline $\begin{array}{l}\text { Stability of the colored } \\
\text { species }\end{array}$ & $1-60 \mathrm{~min}$ & $5 \min$ & $\begin{array}{l}\text { The colored species after separation } \\
\text { from organic layer was stable for } 60 \\
\text { min, afterwards the absorbance } \\
\text { gradually decreased. }\end{array}$ \\
\hline
\end{tabular}

Table 2. Optimum conditions established for NB 12BR and AG

\begin{tabular}{|c|c|c|c|}
\hline Parameter & $\begin{array}{l}\text { Optimum } \\
\text { range }\end{array}$ & $\begin{array}{l}\text { Conditions in } \\
\text { procedure }\end{array}$ & Remarks \\
\hline $\begin{array}{l}\text { Effect of acid } \\
\text { concentration or } \\
\text { buffer pH on color } \\
\text { development }\end{array}$ & $\begin{array}{l}0.08-0.12 \mathrm{~N} \\
\mathrm{HCl} \text { for } \mathrm{NB} \\
12 \mathrm{BR} \\
1.0-1.8(\mathrm{pH}) \\
\text { for } \mathrm{AG}\end{array}$ & $\begin{array}{l}0.1 \mathrm{~N} \mathrm{HCl} \\
\text { for } \mathrm{NB} \\
12 \mathrm{BR} \\
\mathrm{pH}-1.5 \\
\text { for } \mathrm{AG}\end{array}$ & $\begin{array}{l}\text { Variations of concentrations of the acid } \\
\text { or pH of the buffer beyond the upper } \\
\text { and lower limits resulted in low } \\
\text { absorbance values. }\end{array}$ \\
\hline
\end{tabular}




\begin{tabular}{|c|c|c|}
\hline $\begin{array}{l}\text { Volume of acid or } \\
\text { buffer required for } \\
\text { maximum intensity of } \\
\text { color }\end{array}$ & $\begin{array}{r}5.0-7.0 \mathrm{~mL} \quad 6 \mathrm{~mL} \text { of acid } \\
\text { acid or buffer(for B12BR) } \\
\text { or buffer (AG) }\end{array}$ & $\begin{array}{l}\text { Variation of volume of buffer or acid } \\
\text { beyond the lower limit resulted in low } \\
\text { absorbance values. }\end{array}$ \\
\hline $\begin{array}{l}\text { Effect of volume of } \\
\text { dye }\end{array}$ & $1.0-2.5 \mathrm{~mL}$ & $\begin{array}{l}2.0 \mathrm{~mL} \text { of } \mathrm{NB} 12 \mathrm{BR} \text { and } \mathrm{AG} \text { was } \\
\text { necessary for covering the broad range } \\
\text { of Beer's law. }\end{array}$ \\
\hline $\begin{array}{l}\text { Choice of the } \\
\text { organic solvent for } \\
\text { the extraction of the } \\
\text { colored species }\end{array}$ & Chloroform & $\begin{array}{l}\text { The other water immiscible solvents } \\
\text { tested for the extraction of the colored } \\
\text { complex into organic phase include } \\
\text { chlorobenzene, dichloromethane, carbon } \\
\text { tetrachloride, } n \text {-butanol and benzene. } \\
\text { Chloroform was preferred for its } \\
\text { selectivity extraction of the complex from } \\
\text { the aqueous phase. }\end{array}$ \\
\hline $\begin{array}{l}\text { Effect of the ratio of } \\
\text { aqueous to organic } \\
\text { phase on extraction }\end{array}$ & $3: 2$ & $\begin{array}{l}\text { The extraction of the colored species } \\
\text { into chloroform layer was incomplete } \\
\text { where the ratio of aqueous to } \\
\text { chloroform phase was more than the } \\
\text { specified ratio in each case. }\end{array}$ \\
\hline $\begin{array}{l}\text { Effect of shaking } \\
\text { time }\end{array}$ & $1-5 \mathrm{~min}$ & $\begin{array}{l}\text { Constant absorbance values were } \\
\text { obtained for the shaking period 3-8 min. }\end{array}$ \\
\hline $\begin{array}{l}\text { Effect of } \\
\text { temperature on the } \\
\text { colored species }\end{array}$ & $\begin{array}{cl}\text { Laboratory } & \text { Laboratory } \\
\text { temperature } & \text { temperature } \\
\left(28+2^{0} \mathrm{C}\right) & \end{array}$ & $\begin{array}{l}\text { At low temperature }\left(<20^{\circ} \mathrm{C}\right) \text { the } \\
\text { extraction of the colored species was } \\
\text { found to be improper. At high } \\
\text { temperature }\left(>35^{\circ} \mathrm{C}\right) \text { the stability of the } \\
\text { colored species was found to be less. }\end{array}$ \\
\hline $\begin{array}{l}\text { Stability of the } \\
\text { colored species }\end{array}$ & $1-60 \mathrm{~min}$ & $\begin{array}{l}\text { The colored species after separation from } \\
\text { organic layer was stable for } 60 \text { min, } \\
\text { afterwards the absorbance gradually } \\
\text { decreased. }\end{array}$ \\
\hline
\end{tabular}

Table 3. Optical, regression characteristics of the proposed methods for GFX

\begin{tabular}{lllll}
\hline \multicolumn{1}{c}{ Parameter } & SFN O & MB & NB 12BR & AG \\
\hline$\lambda_{\max }, \mathrm{nm}$ & 525 & 650 & 620 & 540 \\
Beer's law limits, $\mu \mathrm{g} \mathrm{mL}^{-1}$ & $3.0-15.0$ & $4.0-20.0$ & $2.0-10.0$ & $2.0-10.0$ \\
Detection limits, $\mu \mathrm{g} \mathrm{mL}^{-1}$ & 0.058 & 0.074 & 0.045 & 0.053 \\
Molar absorptivity, $\mathrm{Lmole}^{-1} \mathrm{~cm}^{-1}$ & $2.81 \times 10^{4}$ & $2.20 \times 10^{4}$ & $4.02 \times 10^{4}$ & $4.15 \times 10^{4}$ \\
Sandell's sensitivity & 0.017 & 0.022 & 0.012 & 0.0116 \\
$\mu \mathrm{g} \mathrm{cm} \mathrm{cm}^{-2}$ 0.001 absorbance unit) & & & & \\
Regression equation (Y=a + bC) & & & & \\
Slope (b) & $5.7 \times 10^{-2}$ & $4.5 \times 10^{-2}$ & $8.2 \times 10^{-2}$ & $8.5 \times 10^{-2}$ \\
Standard deviation of slope $\left(\mathrm{S}_{\mathrm{b}}\right)$ & $0.11 \times 10^{-3}$ & $0.09 \times 10^{-3}$ & $0.19 \times 10^{-3}$ & $0.23 \times 10^{-3}$ \\
Intercept (a) & $0.5 \times 10^{-3}$ & $0.50 \times 10^{-3}$ & $0.30 \times 10^{-3}$ & $1.20 \times 10^{-3}$ \\
Standard deviation of intercept $\left(\mathrm{S}_{\mathrm{a}}\right)$ & $1.13 \times 10^{-3}$ & $1.13 \times 10^{-3}$ & $1.26 \times 10^{-3}$ & $1.53 \times 10^{-3}$ \\
\hline & & & & $\mathrm{Contd} \ldots$
\end{tabular}




\begin{tabular}{|c|c|c|c|c|}
\hline Standard error of estimation $\left(\mathrm{S}_{\mathrm{e}}\right)$ & $1.08 \times 10^{-3}$ & $1.08 \times 10^{-3}$ & $1.20 \times 10^{-3}$ & $1.46 \times 10^{-3}$ \\
\hline Correlation coefficient (r) & 0.9999 & 0.9999 & 0.9999 & 0.9999 \\
\hline $\begin{array}{l}\text { Relative standard deviation, } \%^{a} \\
\% \text { Range of error } \\
\text { (Confidence limits) }^{a}\end{array}$ & 0.077 & 0.104 & 0.080 & 0.103 \\
\hline 0.05 level & 0.064 & 0.087 & 0.067 & 0.086 \\
\hline 0.01 level & 0.095 & 0.129 & 0.100 & 0.128 \\
\hline$\%$ Error in bulk samples ${ }^{b}$ & 0.072 & 0.138 & 0.075 & -0.036 \\
\hline
\end{tabular}

Table 4. Results of analysis of tablet formulations containing GFX

\begin{tabular}{|c|c|c|c|c|c|c|c|c|c|}
\hline \multirow[t]{2}{*}{ Formulation } & \multirow{2}{*}{$\begin{array}{c}\text { Labeled } \\
\text { amount } \\
\text { mg }\end{array}$} & \multicolumn{5}{|c|}{ \% Recovery* } & \multicolumn{3}{|c|}{$\%$ RSD } \\
\hline & & SFN O & MB & NB $12 B R$ & $A G$ & SFN O & $\mathrm{MB}$ & NB $12 B R$ & $\mathrm{AG}$ \\
\hline Tabl & 320 & 100.03 & 100.01 & 99.99 & 100.08 & 0.49 & 0.38 & 0.44 & 0.56 \\
\hline Tablets- 2 & 320 & 100.06 & 100.0 & 100.02 & 100.06 & 0.57 & 0.53 & 0.41 & 0.32 \\
\hline
\end{tabular}

* Average of six independent analyses.

Table 5. Results of recovery study by standard addition method

\begin{tabular}{|c|c|c|c|c|c|c|c|c|c|}
\hline \multirow{2}{*}{ Formulation } & \multirow{2}{*}{$\begin{array}{l}\text { Amount } \\
\mu \mathrm{g} \mathrm{mL} \mathrm{L}^{-1} \\
\text { Taken } \\
+ \text { Added }\end{array}$} & \multicolumn{4}{|c|}{ \% Recovery* } & \multicolumn{4}{|c|}{$\%$ RSD } \\
\hline & & SFN O & MB & NB & AG & SFN O & MB & NB $12 B R$ & $\mathrm{AG}$ \\
\hline \multirow[t]{2}{*}{ Tablets-1 } & $4+5$ & 10 & 0.01 & 100 & & 0.5 & 0.29 & 0.5 & 0.4 \\
\hline & $5+5$ & 100.03 & 100.02 & 100.10 & 100.08 & 0.47 & 0.35 & 0.55 & 0.57 \\
\hline \multirow[t]{2}{*}{ Tablets-2 } & $4+4$ & 100.0 & 100.08 & 100.12 & 100.04 & 0.36 & 0.54 & 0.61 & 0.50 \\
\hline & $5+4$ & 100.02 & 100.06 & 100.09 & 100.16 & 0.51 & 0.38 & 0.53 & 0.54 \\
\hline
\end{tabular}

* Average of six independent analyses

In conclusion the proposed spectrophotometric methods for the estimation of GFX were simple, sensitive and accurate and can be used for the routine quality control of the drug in bulk as well as in pharmaceutical formulations.

\section{References}

1. Oh J I, Pack M J, Ahn M Y, Kim CY, Hong C Y, Kim I C and Kwak J H, Antimicrob Agents Chemother., 1996, 40, 1564.

2. Cormican M G and Jones R N. Antimicrob Agents Chemother., 1997, 41, 204.

3. Hohl A F, Frei R, Ponter V, Von graevenitz A, Knapp C, Washington J, Johnson D and Jones R N. Clin Microbiol Infect., 1998, 4, 280.

4. Doyle E, Fowles S E, Mc Donnell D F, Mc Carthy and White S A. J. Chromatogr., B. 2000, 746, 191.

5. Ramji J V, Austin N E, Boyle G W, Chalker M H, Duncan G, Fairless A J, Hollis F J, Mc Donnell D F, Musick T J and Shardlow P C. Drug Metabolisam and Disposition, 2001, 29, 435.

6. Seung I 1 Cho, Jiyeon Shim, Min-su kim, Yong-kweon kim and Doo soo chung. $J$. Chromatogr., A. 2004, 1055, 241.

7. Won jae Lee and Chang Yang Hong. J. Chromatogr., A. 2000, 879, 113.

8. Eun sook kim, Yoo-mo koo and Doo soo chung. J.Chromatogr., A. 2004, 1045, 119. 


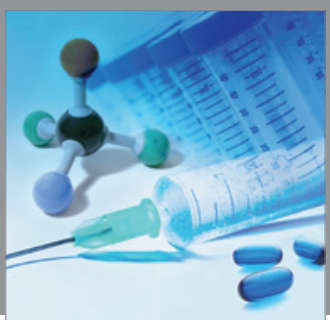

International Journal of

Medicinal Chemistry

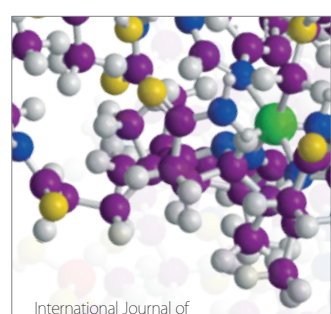

Carbohydrate Chemistry

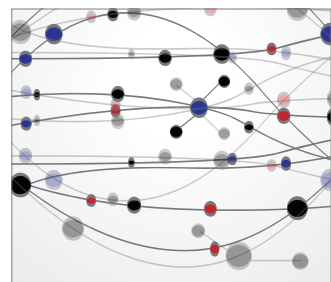

The Scientific World Journal
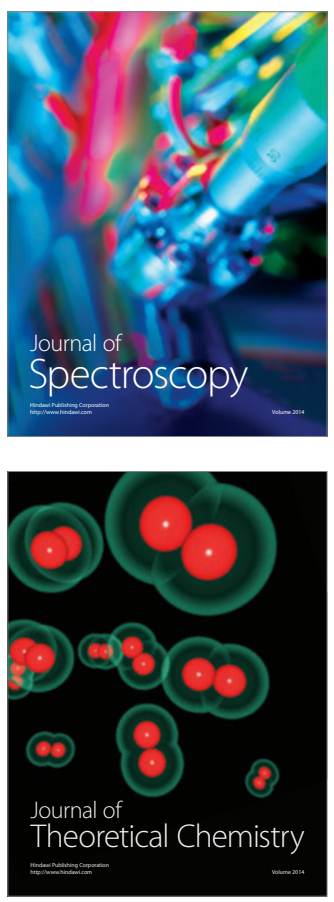
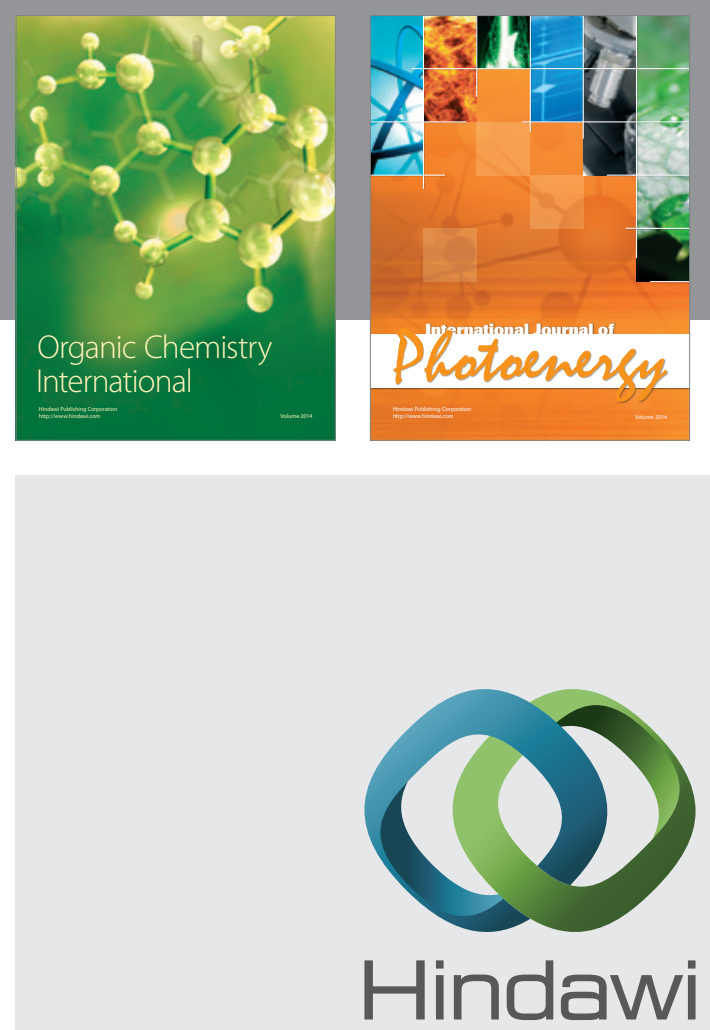

Submit your manuscripts at

http://www.hindawi.com
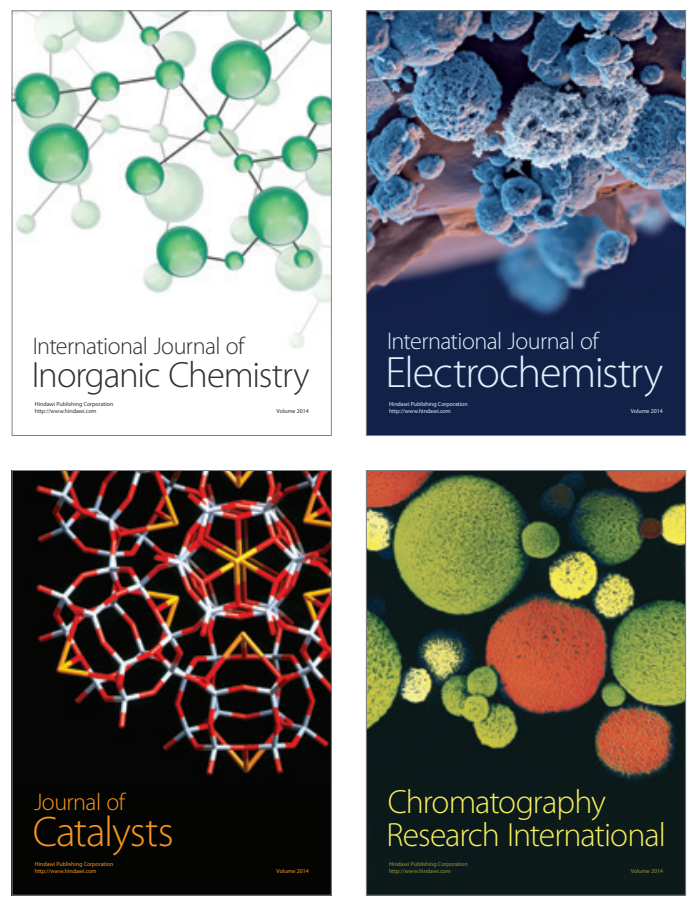
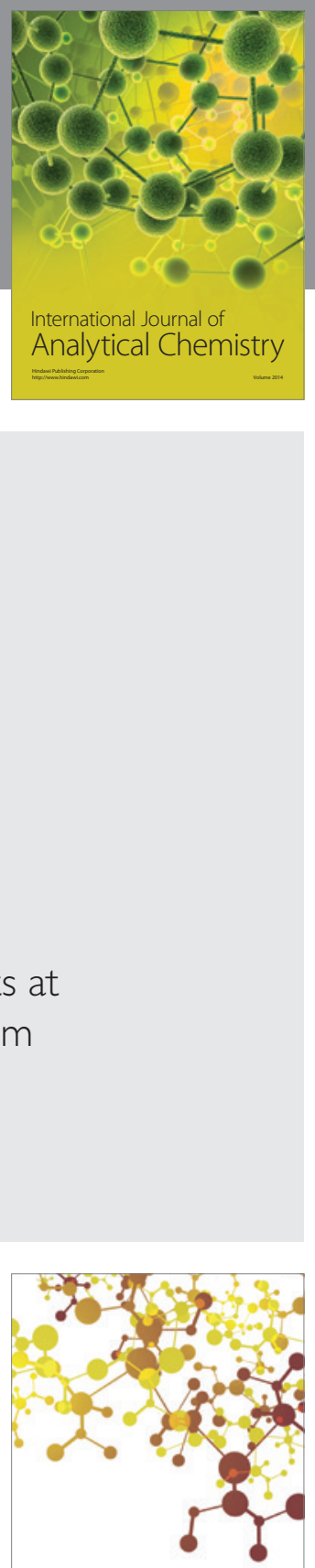

Journal of

Applied Chemistry
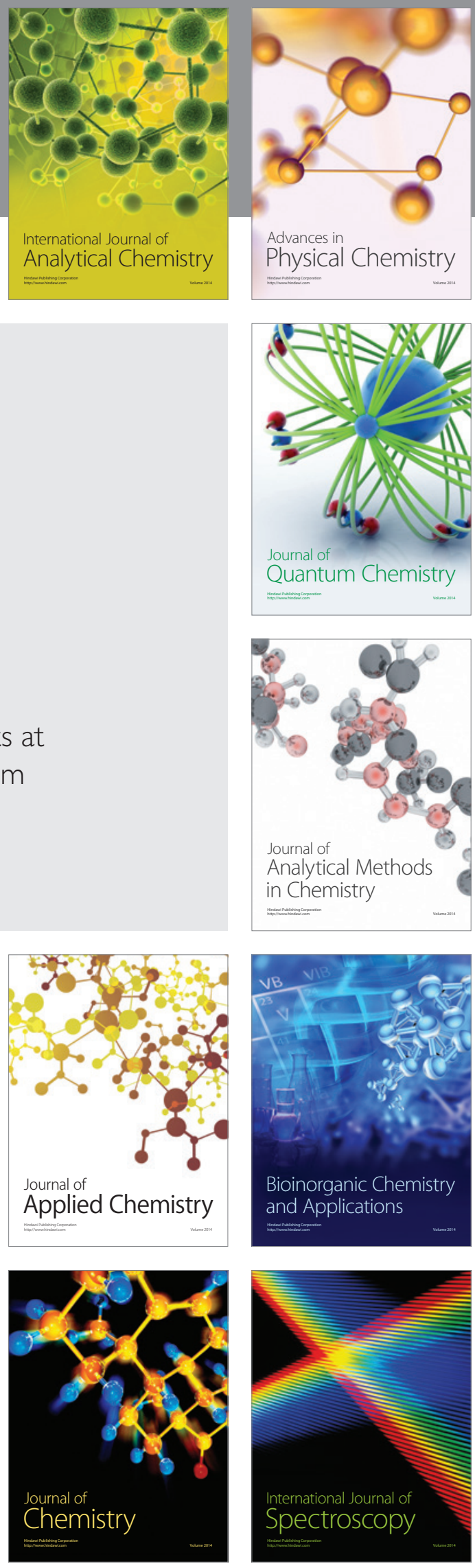